\title{
Characterization of people with hemato-oncological diseases admitted to an emergency unit
}

\author{
Caracterização das pessoas com doença hemato-oncológica atendidas em uma unidade de \\ urgência e emergência

\section{Caracterización de personas con enfermedad hemato-oncológica atendidas en una unidad de urgencia y emergencia}

\section{Jéssica Luíza Beck ${ }^{1}$ \\ Silvana Bastos Cogo $^{1}$ \\ Thaís Dresch Eberhardt ${ }^{1}$ (i) \\ Ariele Priebe Reisdorfer ${ }^{1}$ (D) \\ Tais Falcão Gomes ${ }^{1}$}

Nara Marilene Oliveira Girardon Perlini ${ }^{1}$ (C)

1. Universidade Federal de Santa Maria.

Santa Maria, RS, Brasil.
Corresponding author:

Ariele Priebe Reisdorfer.

E-mail: arielereisdorfer@hotmail.com

Submitted on $02 / 05 / 2019$

Accepted on 04/26/2019.

DOI: 10.1590/2177-9465-EAN-2019-0021

\begin{abstract}
Objectives: To identify the demographic and clinical profile and the reasons for seeking care of people with hemato-oncological diseases attended at an emergency unit. Methods: This descriptive, correlational, quantitative study was carried in the emergency unit of a general teaching hospital in the state of Rio Grande do Sul, with a sample of 65 patients with hemato-oncological diseases. Simple descriptive statistics were used for the evaluation of the data. Results: There was a predominance of males $(61.5 \%)$, with a mean age of $63.4 \pm 1.7$ years, of white skin color $(95.4 \%)$, with incomplete elementary education (55.4\%) and married (53.8\%). There was a high rate of patients with cancer receiving end-of-life care $(52.3 \%)$, a prevalence of palliative care $(55.4 \%)$, with the outcome most observed being discharge from the unit $(52.3 \%)$. According to the primary site of the cancer, a predominance of lymphomas and leukemias was observed (30.8\%). Regarding the reason for attending the unit, pain $(41.5 \%)$ was the most prevalent symptom. Conclusion and implications for practice: Identifying these characteristics can contribute to nursing care for patients with hemato-oncological diseases, considering the specificity of this care and the care practice in emergency units.
\end{abstract}

Keywords: Emergencies; Quality of life; Neoplasms; Hematology.

\section{Resumo}

Objetivos: Identificar o perfil demográfico, clínico e os motivos de busca de atendimento de pessoas com doenças hemato-oncológicas atendidas em uma unidade de urgência e emergência. Métodos: Trata-se de um estudo quantitativo correlacional, descritivo, realizado na unidade de urgência e emergência de um hospital geral do interior do Rio Grande do Sul, com uma amostra de 65 pessoas com doenças hemato-oncológicas. Para a avaliação dos dados, utilizou-se estatística descritiva simples. Resultados: Houve predomínio do sexo masculino (61,5\%), com média de idade de $63,4 \pm 1,7$ anos, de raça branca $(95,4 \%)$, com ensino fundamental incompleto $(55,4 \%)$ e casado $(53,8 \%)$. Evidenciou-se maior taxa de pessoas com câncer nos cuidados de final de vida $(52,3 \%)$, prevalência dos cuidados paliativos $(55,4 \%)$ e o desfecho mais observado foi a alta da unidade (52,3\%). De acordo com o sítio primário do câncer, foi observada a predominância de linfomas e leucemias (30,8\%). Quanto ao motivo da busca, a dor $(41,5 \%)$ foi o sintoma mais prevalente. Conclusão e implicações para a prática: Conhecer essas características pode contribuir com as ações do enfermeiro no cuidado às pessoas com doenças hemato-oncológicas, considerando a especificidade dessa assistência e a prática do cuidado nas unidades de urgência e emergência.

Palavras-chave: Emergências; Qualidade de vida; Neoplasias; Hematologia.

\section{Resumen}

Objetivos: Identificar el perfil demográfico, clínico y los motivos de búsqueda de atención de personas con enfermedades hemato-oncológicas atendidas en una unidad de urgencia y emergencia. Métodos: Estudio cuantitativo correlacional, descriptivo, realizado en la unidad de urgencia y emergencia de un hospital general del interior de Rio Grande do Sul, con una muestra de 65 personas con enfermedades hemato-oncológicas. Para la evaluación de los datos, se utilizó estadística descriptiva simples. Resultados: Hubo predominancia de hombres (61,5\%), con una edad media de 63,4 $\pm 1,7$ años, raza blanca (95,4\%), con educación primaria incompleta $(55,4 \%)$ y casados $(53,8 \%)$. Se evidenció mayor tasa de personas con cáncer en los cuidados de final de vida $(52,3 \%)$, prevalencia de los cuidados paliativos $(55,4 \%)$ y el comportamiento más observado fue el alta de la unidad (52,3\%). Como sitio primario del cáncer, se observó el predominio de linfomas y leucemias (30,8\%). En cuanto a la razón de la búsqueda, el dolor $(41,5 \%)$ fue el síntoma más frecuente. Conclusión e implicaciones para la práctica: Conocer estas características puede contribuir con las acciones del enfermero ante las personas con enfermedades hemato-oncológicas, considerando la especificidad de esta asistencia y la práctica de la atención en urgencia y emergencia.

Palabras clave: Emergencias; Calidad de Vida; Neoplasias; Hematología. 


\section{INTRODUCTION}

Non-communicable diseases and injuries (NCDIs) are an important public health problem, accounting for 41 million deaths per year and $72 \%$ of deaths worldwide. ${ }^{1}$ The low to middle income countries are the most affected by deaths due to NCDIs. ${ }^{1}$ In Brazil, the population presents a gradual increase in the prevalence of NCDIs, such as cancers and cerebrovascular, cardiac, pulmonary and neurodegenerative diseases, among others. In addition to the change in the epidemiological profile, it is also possible to verify an increase in longevity and, with this, the occurrence of increased rates of death in the higher age groups, with the highest population proportion of older adults being in the south of the country. ${ }^{2,3}$ Accordingly, in Brazil, the occurrence of 600 thousand new cases of cancer is estimated for each year of the 2018-2019 biennium. With the exception of non-melanoma skin cancer (approximately 170 thousand new cases), 420 thousand cases will arise. The World Health Organization (WHO) emphasizes that cancer represents a major public health problem, especially among developing countries, where it is expected that in the next decades the impact of this clinical condition will correspond to $80 \%$ of the more than 20 million cases estimated for 2025. . $^{4}$

In the context of health care networks, which include care for people with hemato-oncological diseases, emergency units stand out, these being important components of the national health system, caring for people with acute illnesses, with or without risk of death. They include professionals prepared to provide immediate assistance to these people, aiming to reduce morbidity and mortality and incapacitating sequelae. ${ }^{5,6}$ With this approach, some oncological emergencies referred to these units have a sudden onset, while others may take months to develop, manifesting abruptly or in hours, resulting in complications and aggravations, which can lead to death. ${ }^{7,8}$

The care is complex in the more advanced stages of the disease, requiring an increase in the period of health care, often associated with loss of independence and decreased quality of life. Professional end-of-life care support is generally performed in the hospital environment, and hospitalizations for chronic illness are usually treated as isolated episodes, with fragmentation of the treatment, without planning for continued care in the advanced stages. ${ }^{3}$ In addition, people with hematooncological diseases, due to the characteristics and specificities of their health condition, repeatedly attend the emergency unit in certain periods and, therefore, present greater care requirements. ${ }^{9}$ These people have an impact on the inflow, contributing to overloading, overcrowding and implying increased costs for the health system. ${ }^{10}$

With regard to the organization of the Oncology Care Networks (OCN), Ordinance No. 741/05 promotes a reconfiguration of the criteria for the accreditation of high complexity oncology units, adopting the following categories: High Complexity Oncology Unit (Unidade de Alta Complexidade em Oncologia - UNACON), High Complexity Oncology Care Centers (Centros de Assistência de Alta Complexidade em Oncologia - CACON) and High Complexity Oncology Referral Centers. The UNACON is found in hospitals with technical conditions, physical facilities, equipment and human resources adequate to provide care related to the diagnosis and treatment of the cancers that are most prevalent in the country, while the CACON is related to hospitals that have these conditions for the diagnosis and treatment of all the types of cancers. ${ }^{11,12}$

People undergoing hemato-oncological treatment normally experience at least one emergency during the course of the disease, with the development of new treatments resulting in prolonged life and an increase in the number of emergencies experienced. ${ }^{7}$ However, regardless of their survival time, these patients frequently need palliative care. People receiving end-of-life care and those whose estimated survival is hours or days, based on the symptomatology and clinical evidence, are included in this context. Due to the many particularities of the treatment and events related to the course of hemato-oncological diseases, it is necessary to deepen the knowledge regarding which people attend the emergency unit. With this the need can be verified for the professionals who work in this care to receive specific training to act and manage the disease process of these people in order to guarantee integrative and quality care in the emergency units.

In view of the above, this study aimed to identify the demographic and clinical profile of the people with hematooncological diseases treated in an emergency unit and the reasons they sought the care.

\section{METHODS}

This was a cross-sectional, descriptive, correlational study conducted in the emergency unit of a tertiary-level public, teaching, general hospital in the state of Rio Grande do Sul. Since its foundation in 1970, this hospital has been a reference in health for the region, acting as a teaching hospital, focused on the development of teaching, research and health care. The hemato-oncology unit of the institution was authorized by the Ministry of Health as a UNACON, being responsible for the integrative care of hemato-oncological patients, including emergency and/or urgency situations that are attended in the emergency unit of the general hospital where the study was developed. It is important to emphasize that this sector does not offer open access for the population, except for those undergoing hemato-oncological treatment, respecting, therefore, the status as a UNACON that requires integrative care for these people. 
The emergency unit of the hospital attends adults and children in separate structures, however, in this study, the scenario was the adult care unit, composed of 43 hospitalization beds, including isolation beds. The study participants were people with hemato-oncological diseases, aged 18 or over admitted to the emergency unit from June to September 2017, routinely and daily monitored in the morning, afternoon and evening shifts. This study solely and exclusively used the hospitalization history from the electronic medical records. Accordingly, medical records that did not present a diagnosis of hemato-oncological diseases were excluded.

The variables were collected through a form designed by the researchers that included: sex (female, male); age (years); race (yellow, white, indigenous, brown, black); origin (Santa Maria, other cities); level of education; marital status; primary site of neoplasm; oncological disease stage (I, II, III, IV); presence of comorbidities (yes, no); type of treatment (curative, palliative); time since hemato-oncological diagnosis (years), data related to the oncological emergencies/reasons for attending; length of stay in the emergency unit, length of stay in the hospital (in days): and outcome of the hospitalization (discharge, hospitalization, death).

Data were analyzed using the Statistical Package for the Social Sciences (SPSS) for Windows, version 21. Simple descriptive statistical analysis was performed. The qualitative variables were described by means of absolute and relative frequency. The quantitative variables were described by means of central tendency (mean or median) and dispersion (standard error or interquartile range), according to their distribution.

The study is part of a larger project entitled "Assistência a pessoas em tratamento oncológico em situações de urgência e/ou emergência em um serviço de pronto-socorro", approved by the Ethics Committee for Research with Human Subjects of the Federal University of Santa Maria (UFSM) under CAAE No. 69116717.9.0000.5346, and approved with authorization No. 2.121.624 on May 31, 2016, following the guidelines of Resolution $466 / 12$ of the National Health Council.

\section{RESULTS}

The data collected in this study make up the demographic and clinical characterization of the people attending the emergency unit, as well as the reasons for seeking care. Thus, of the 972 patients treated in the emergency unit during the study period, 65 people with hemato-oncological diseases were included, as shown in Figure 1.

The participants of this study were predominantly male $(61.5 \%)$, with a mean age of $63.4 \pm 1.7$ years, of white race (95.4\%), from Santa Maria $(58.5 \%)$, with incomplete fundamental education (55.4\%) and married (53.8\%) - Table 1.
Figure 1. Flowchart for the selection of the study participants in relation to the characteristics of people with hemato-oncological diseases admitted to the emergency unit. Santa Maria, RS, Brazil, 2017. Source: prepared by the authors.

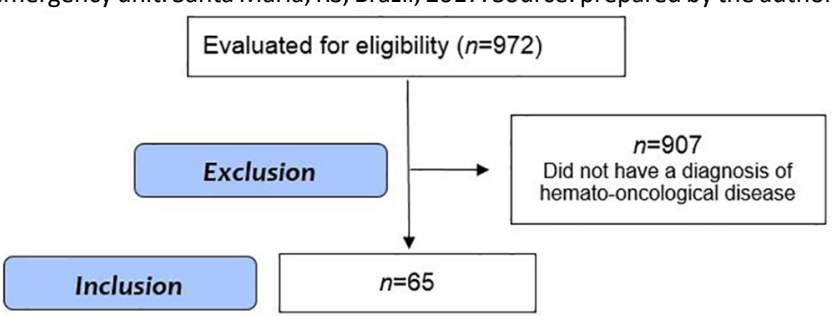

Table 2 shows the clinical characteristics of the people diagnosed with hemato-oncological diseases. There was a higher rate of people with stage IV cancer receiving end-of-life care (52.3\%), with comorbidities (73.8\%) and a prevalence of palliative care $(52.3 \%)$. The most observed outcome was discharge from the unit $(52.3 \%)$.

Regarding the primary site of the neoplasm in the people with hemato-oncological disease, there was a predominance of lymphomas and leukemias (30.8\%), followed by gastrointestinal (24.6\%) and breast (15.4\%) tumors, as shown in Figure 2.

Regarding the main clinical manifestations that motivated people to seek care in the emergency unit, it was found that some patients presented more than one manifestation. However, pain $(41.5 \%)$, fever $(18.5 \%)$ and nausea and vomiting $(16.9 \%)$ were the main complaints at the time of admission, followed by dyspnea $(13.8 \%)$, asthenia $(10.8 \%)$, coughing $(10.8 \%)$, lack of appetite $(9.2 \%)$, paresthesia $(9.2 \%)$, dysphagia $(6.2 \%)$, bleeding $(4.6 \%)$, syncope $(3.1 \%)$ and paraplegia $(3.1 \%)$. Other clinical manifestations, such as headache, sensorial loss, mental confusion, anemia, referred to only once per person and categorized as "others" (20\%), were also described.

\section{DISCUSSION}

The characterization of the people treated in the emergency unit, presents relevant information, similar to that observed in other studies. Through this approach, the data collected showed the mean age of the individuals of 63.4 years, which is in agreement with the literature, as one study evaluated that the main causes of mortality in older adults to be due to circulatory system and hemato-oncology diseases, with diseases of the circulatory system account for more than $55 \%$ of deaths in people aged between 60 and 69 years. Hemato-oncological diseases are responsible for more than $45 \%$ of deaths in people aged 80 years or over, with a trend towards a gradual increase in mortality rates, which can be justified by the body's exposure to the carcinogenic factors for more time due to aging. ${ }^{13}$ 
Table 1. Distribution of people with hemato-oncological diseases admitted to the emergency unit according to demographic characteristics ( $n=65)$. Santa Maria, RS, Brazil, 2017.

\begin{tabular}{|c|c|c|c|}
\hline Variable & $\mathbf{n}$ & $\%$ & $95 \% \mathrm{Cl}$ \\
\hline \multicolumn{4}{|l|}{ Sex } \\
\hline Male & 40 & 61.5 & $49.2-73.8$ \\
\hline Female & 25 & 38.5 & $26.2-50.8$ \\
\hline \multicolumn{4}{|l|}{ Skin color } \\
\hline White & 62 & 95.4 & $89.2-100$ \\
\hline Black & 3 & 4.6 & $0.0-10.8$ \\
\hline \multicolumn{4}{|l|}{ Origin } \\
\hline Santa Maria & 38 & 58.5 & $46.2-70.7$ \\
\hline Other city & 27 & 41.5 & $29.3-53.8$ \\
\hline \multicolumn{4}{|l|}{ Level of education } \\
\hline Uneducated & 6 & 9.2 & $3.1-16.9$ \\
\hline Incomplete elementary education & 36 & 55.4 & $44.6-67.7$ \\
\hline Complete elementary education & 12 & 18.5 & $9.2-27.7$ \\
\hline Incomplete high school education & 2 & 3.1 & $0.0-7.7$ \\
\hline Complete high school education & 9 & 13.8 & $6.2-23.1$ \\
\hline \multicolumn{4}{|l|}{ Marital status } \\
\hline Single & 16 & 24.6 & $15.4-36.9$ \\
\hline Married & 36 & 55.4 & $43.1-66.2$ \\
\hline Divorced & 5 & 7.7 & $1.5-13.8$ \\
\hline Widowed & 8 & 12.3 & $4.6-20.0$ \\
\hline Variable & Mean & SE & Min - Max \\
\hline Age (years) & 63.4 & 1.7 & $25-88$ \\
\hline
\end{tabular}

95\% Cl: 95\% Confidence Interval; SE: Standard error; Min: Minimum value; Max: Maximum value.

The global estimates for the year 2030, according to the WHO, indicate 21.4 million new cases of cancer and 13.2 million deaths from cancer. This is due to population growth and aging, as well as the decline in infant mortality and in the percentage of deaths from infectious diseases. ${ }^{12}$ Other studies also show the predominance of the male sex in the patients of emergency units of public hospitals. This fact is mainly due to the greater male exposure to urban violence. ${ }^{14,15}$ Absence of a partner can be a barrier to seeking help/care, which may have characterized the higher rate of married people that attended the emergency unit of the present study.

Regarding the low educational level observed in this study, it is known that the education level is indicated as a predictive factor for the development of some types of cancer. This can be attributed to a greater restriction in the range of information regarding the forms of prevention and early diagnosis, as well as the greater difficulty in accessing the health services. ${ }^{16}$ These results are also in line with another study that presented the profile of 147 cancer patients undergoing radiotherapy at a Regional Oncology Center in Southern Brazil, in which the authors verified that low education levels interfered with their understanding regarding the treatment, self-care and the relationship between the patient and professional. ${ }^{17}$

In the present study, a mean of five days of hospitalization in the emergency unit was observed. A study carried out in a hospital of Rio de Janeiro (RJ) evaluated the length of stay in the emergency unit, and presented a mean of six days of hospitalization..$^{18}$ In the emergency unit, the lack of privacy associated with the agitated and overcrowded environment may result in loss of autonomy. ${ }^{19}$ Another study carried out in the adult emergency unit of a public general hospital located in the state of Santa Catarina characterized the prolonged hospitalization time in these units as a challenge associated with the difficulty of referral. This stay of more than 24 hours affects the real cases of emergency, aggravating the overcrowding ${ }^{20}$. It should be emphasized that the National Policy on Emergency Care recommends that the care provided to people in emergency units be for up to 24 hours. ${ }^{21}$ 
Table 2. Distribution of people with hemato-oncological diseases admitted to the emergency unit according to clinical characteristics ( $n=65)$. Santa Maria, RS, Brazil, 2017.

\begin{tabular}{|c|c|c|c|}
\hline Variable & $\mathbf{n}$ & $\%$ & $95 \% \mathrm{Cl}$ \\
\hline \multicolumn{4}{|l|}{ Stage of disease } \\
\hline Initial/intermediate (I, II, III) & 11 & 16.9 & $7.7-26.2$ \\
\hline Terminal (IV) & 34 & 52.3 & $40.0-64.6$ \\
\hline Hematological & 20 & 30.8 & $18.5-43.0$ \\
\hline \multicolumn{4}{|l|}{ Comorbidities } \\
\hline Yes & 48 & 73.8 & $63.1-83.1$ \\
\hline No & 17 & 26.2 & $16.9-36.9$ \\
\hline \multicolumn{4}{|l|}{ Treatment } \\
\hline Curative & 29 & 44.6 & $32.3-56.9$ \\
\hline Palliative & 36 & 55.4 & $43.1-67.7$ \\
\hline \multicolumn{4}{|l|}{ Outcome of the hospitalization } \\
\hline Discharge & 34 & 52.3 & $44.9-73.5$ \\
\hline Hospitalization & 16 & 24.6 & $12.2-36.7$ \\
\hline Death & 15 & 23.1 & $6.1-26.5$ \\
\hline Variable & Median & IQR & Min - Max \\
\hline Time since diagnosis (in months) & 6.0 & 23.0 & $0-180$ \\
\hline Length of hospitalization in the emergency unit (days) & 5.0 & 5.5 & $1-65$ \\
\hline Length of hospitalization in the hospital (days) & 7.0 & 9.2 & $1-68$ \\
\hline
\end{tabular}

95\%Cl: 95\% Confidence Interval; IQR: Interquartile range; Min: Minimum value; Max: Maximum value.

Figure 2. Primary site of the neoplasm of the people with hemato-oncological disease admitted to an emergency unit. Santa Maria, RS, Brazil, 2017. Source: prepared by the authors.

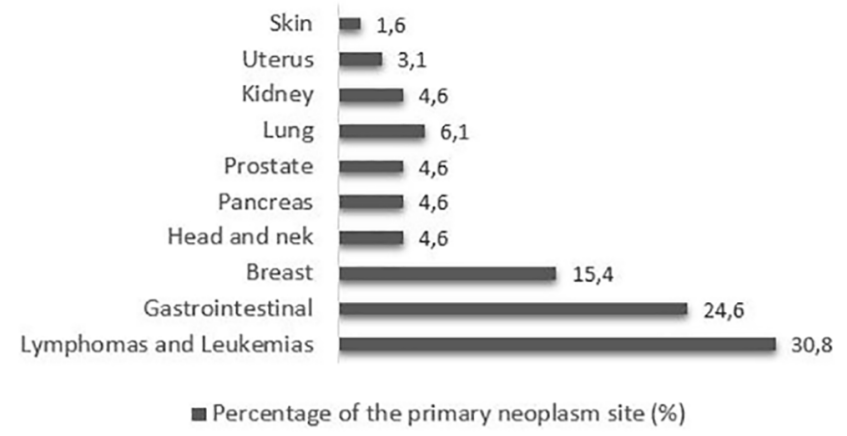

In this study, hospital discharge was the outcome most observed (52.3\%), as was reported in other studies that traced the profile of people with hemato-oncological diseases that attended emergency units in the South and Southeast regions of Brazil. This outcome may be related to the low complexity of the clinical conditions that these people present, which raises the question of whether these needs could have been fulfilled in the primary care network, also evidencing the predilection of these people for seeking emergency units. ${ }^{22,23}$
Emergency care is designed to respond immediately to life-threatening conditions and clinical manifestations. These actions may be preventive, curative, rehabilitative or end-of-life care. ${ }^{24}$ Accordingly, emergencies also include the hematooncological conditions that occur due to the pathology itself and the complications of the treatment instituted or the overlap of both (hypocalcaemia, tumor lysis syndrome), hematological and (febrile neutropenia) structural issues (compression of the spinal cord and peripheral nerves, pericardial effusion) or side-effects of the antineoplastic agents (nausea, vomiting, diarrhea).

In the present study, there was a rate of $55.4 \%$ receiving end-of-life care and in $23.1 \%$ the outcome was death. A study that aimed to analyze the care outcome of people receiving end-of-life care from a home care service with specialized teams, in the period from 2009 to 2011 , observed 3,109 people, where a total of $80 \%$ had cancer and $78 \%$ received end-of-life care through home care, $31.2 \%$ of whom were attended at the hospital and $28.9 \%$ died in the emergency unit. Thus, the authors highlighted the need for home care for these people, aiming to reduce the need for intensive care and deaths in the hospital for those receiving end-of-life care ${ }^{26}$ In agreement with this finding, a study that sought to identify the therapeutic approaches prioritized by health care providers for the person receiving end-of-life care 
in the emergency unit showed that the increase in the incidence of chronic diseases and the lack of resources at the society level has led people with incurable diseases to experience the last moments of life in a hospital context and, in many cases, in the emergency unit. ${ }^{27}$ Thus, the health care providers that perform the care in this unit, are increasingly faced with situations of dying processes that occur in a short space of time. ${ }^{27}$

It was observed that $52.3 \%$ of the people admitted to the emergency unit of the study institution were in the terminal stage of the disease (stage IV). This result contrasts with that of a study that aimed to identify the demographic data of the US population affected by oncological diseases, which verified, through a country wide registration program, that only $20 \%$ of the patients were diagnosed with a terminal stage of the disease. ${ }^{28}$ A study that quantified the recurrence of people undergoing oncological treatment in the Hospital Center of Porto/Santo António Hospital, receiving end-of-life care in the emergency unit, emphasized that, in people with the advanced stage of the disease (stage IV), acute situations often arose, many of which were predictable and not controllable outside the hospital environment. Some examples of acute situations considered to be emergencies in people receiving end-of-life care are exacerbation of the pain, dyspnea and bleeding, justifying seeking a hospital resource, where the family/caregiver feels powerless in these manifestations, and the emergency unit is the solution found at the time. ${ }^{29}$

Unlike that found in the present study, which highlighted the prevalence of lymphomas and leukemias, a retrospective exploratory study carried out in an emergency unit in São Paulo state showed that, of a total of 172 people attended, $27.4 \%$ had gastrointestinal oncological disease, followed by lung $18.6 \%$ and breast $16.9 \%$ tumors, while cases of people with lymphoma were $5.8 \%{ }^{30}$. Another study performed in different institutions in the United States showed that people with cancer due to pulmonary, gastrointestinal and genitourinary neoplasms were the ones that attended the general emergency service most. ${ }^{31}$

A study aimed at identifying and characterizing potentially preventable hospitalizations in the United States found a total of 2,713 people with cancer between January 2010 and December 2011 evaluated in a palliative care outpatient clinic. Among these people, $1,841(68 \%)$ used the emergency unit at least once during the study period, with it being verified that pain $(36.0 \%)$ was the most common reason for attending, followed by dyspnea, fever and bleeding. ${ }^{32}$ These findings are in agreement with the data of the present study, where it was observed that pain ( $41.5 \%)$, followed by fever (18.5\%) and nausea and vomiting $(16.9 \%)$, were the main complaints at the time of admission to the unit.

In another study carried out in an emergency unit, a total of 10,792 people were treated in 2012, and of these, 172 had pathologies of oncological origin. Among the main reasons that led these patients to attend this unit were pain $83.1 \%$, nausea and vomiting $67.4 \%$, fever $26.1 \%$ and weakness $11.6 \% .{ }^{30}$ In the same study, another point evaluated was the presence of comorbidities, where the majority $(75.6 \%)$ presented other health conditions, which is similar to the finding in the present study, where $73.8 \%$ of the people also presented comorbidities. ${ }^{30}$ People with hemato-oncological diseases may present complications arising from the disease itself or from the pharmacological therapy they receive. To identify the characteristics of people with hemato-oncological diseases that attend emergency units is therefore important to support the health care providers involved in the care of these people.

\section{CONCLUSIONS AND IMPLICATIONS FOR THE PRACTICE}

It was observed that the majority of people with hematooncological diseases attending the emergency unit were male, white, married and had a mean age above 60 years and incomplete elementary education. The primary site of the neoplasm was evidenced by the predominance of lymphomas and leukemias. Many people presented comorbidities and the main clinical manifestations were pain, fever, nausea and vomiting, which were related to the reason for seeking care. There was an association between the stage of the disease and the length of hospital stay, where the majority of the people with hemato-oncological disease were receiving end-of-life care and the frequent outcome was discharge from the emergency unit within ten days.

The identification of the characteristics of people with hemato-oncological diseases that attend the emergency unit specifically allows a fast and efficient treatment of the symptoms that these people present to be established. People with hemato-oncological diseases sometimes need end-of-life care, which requires the professionals, especially nurses, as this is the professional category that is closest to the patient, to provide humanized, personalized, specialized care and with a focus on the quality of life, until its finitude. This requires training and continued education of the health teams in the most varied levels of care, with constant reflection on the requirements of this care.

Identifying the profile of people with hemato-oncological diseases can contribute to the nurses' performance in the care, considering the specificity of this care and the care practice in emergency units. Also, the profile and reasons for attending the emergency unit provide information to identify preventable factors regarding the return to the unit and the elaboration of nursing care plans that meet the needs of these people, qualifying the care provided by these professionals. Thus, nursing interventions can be planned from data obtained in this study, such as the stage of the disease, type of treatment and 
comorbidities, as well as to stimulate the nurses' clinical reasoning to understand the clinical manifestations presented by people with hemato-oncological disease that seek emergency care and relate them to the basic disease and its stage, instituting individualized and effective care.

The limitations of this study are related to size of the sample, since a period of data collection was defined. The information obtained from the electronic medical records, even when carefully collected, can also be a limitation, considering that it is information provided by professionals that complete this during the care, with the possibility of incomplete records. Another limitation was that this study was developed in a single health institution, which generates the stimulus to develop new studies in this area in emergency units of public, private and philanthropic hospitals.

\section{REFERENCES}

1. Organização Mundial da Saúde (OMS). Organização Pan-Americana da Saúde (OPAS). Investir no controle de doenças crônicas não transmissíveis gera grandes retornos financeiros e de saúde. Brasil: Ministério da Saúde; 2018 mai; [cited 2018 jul 19]. Available from: https:// www.paho.org/bra/index.php?option=com_content\&view=article\&id=5 675:investir-no-controle-de-doencas-cronicas-nao-transmissiveis-geragrandes-ganhos-financeiros-e-de-saude-afirma-oms\&ltemid=839

2. Junior RT, Loffredo LCM. Mortalidade de idosos em município do Sudeste brasileiro de 2006 a 2011. Ciênc. Saúde Coletiva [Internet]. 2014 mar; [cited 2019 apr 20]; 19(3):975-84. Available from: http:// www.scielo.br/pdf/csc/v19n3/1413-8123-csc-19-03-00975.pdf DOI: 10.1590/1413-81232014193.10482012

3. Marcucci FCl, Cabrera MAS. Morte no hospital e no domicílio: influências populacionais e das políticas de saúde em Londrina, Paraná, Brasil (1996 a 2010). Ciênc Saúde Coletiva [Internet]. 2015 mar; [cited 2018 aug 31]; 20(3):833-40. Available from: http://www.scielo.br/pdf/ csc/v20n3/pt_1413-8123-csc-20-03-00833.pdf DOI: 10.1590/141381232015203.04302014

4. Ministério da Saúde (BR). Instituto Nacional de Câncer José Alencar Gomes da Silva - INCA. Estimativa 2016: incidência de câncer no Brasil [Internet]. Rio de Janeiro: INCA. 2015; [cited 2018 aug 21]. Available from: http://santacasadermatoazulay.com.br/wp-content/uploads/2017/06/ estimativa-2016-v11.pdf

5. Azevedo ALCS, Pereira AP, Lemos C, Coelho MF, Chaves LP. Organização de serviços de emergência hospitalar: uma revisão integrativa de pesquisas. Rev Eletr Enferm [Internet]. 2010 out/dez; [cited 2017 dec 10]; 12(4):736-45. Available from: https://www.fen.ufg. br/revista/v12/n4/pdf/v12n4a20.pdf DOI: 10.5216/ree.v12i4.6585

6. Garcia EA, Fugulin FMT. Distribuição do tempo de trabalho das enfermeiras em Unidade de Emergência. Rev Esc Enferm USP [Internet]. 2010 dec; [cited 2018 jul 18]; 44(4):1032-1038. Available from: http:// www.scielo.br/pdf/reeusp/v44n4/25

7. Gabriel J. Acute oncological emergencies. Nursing Standard [Internet]. 2012; [cited 2018 aug 25]; 27(4):35-41. Available from: https://journals. rcni.com/doi/abs/10.7748/ns2012.09.27.4.35.c9308 DOI: 10.7748/ ns2012.09.27.4.35.c9308

8. Sadik M, Ozlem K, Huseyin M, AliAyberk B, Ahmet S, Ozgur O. Attributes of cancer patients admitted to the emergency department in one year. World J Emerg Med [Internet]. 2014; [cited 2018 aug 29]; 5(2):85-90. Available from: https://www.ncbi.nlm.nih.gov/pmc/articles/ PMC4129880/ DOI: 10.5847/wjem.j.issn.1920-8642.2014.02.001
9. Doupe MB, Palatnick W, Day S, Chateau D, Soodeen RA, Burchill C et al. Frequent Users of Emergency Departments: developing standard definitions and defining prominent risk factors. Annals of Emergency Medicine [Internet]. 2012 jul; [cited 2018 aug 23]; 60(1):24-32. Available from: https://www.annemergmed.com/article/S0196-0644(11)01877-4/ fulltext DOI: 10.1016/j.annemergmed.2011.11.036

10. Lacalle EJ, Rabin EJ, Genes NG. High-frequency users of emergency department care. J Emerg Med [Internet]. 2013 jun; [cited 2018 aug 30] 44(6):1167-1173. Available from: https://www.jem-journal.com/article/ S0736-4679(12)01565-X/pdf DOI: 10.1016/j.jemermed.2012.11.042

11. Ministério da Saúde (BR). Portaria no 741, de 19 de dezembro de 2005. Diário Oficial da União [Internet], Brasília (DF). 20 dez 2005; [cited 2017 dec 10]. Available from: http://bvsms.saude.gov.br/bvs/saudelegis/ sas/2005/prt0741_19_12_2005.html

12. Ministério da Saúde (BR). Instituto Nacional de Câncer José Alencar Gomes da Silva - INCA. Estimativa 2014: incidência de câncer no Brasil [Internet]. Rio de Janeiro: INCA. 2014; [cited 2018 aug 21] Available from: http://www.saude.sp.gov.br/resources/ses/perfil/gestor/ homepage/outros-destaques/estimativa-de-incidencia-de-cancer-2014/ estimativa_cancer_24042014.pdf

13. Oliveira TC, Medeiros WR, Lima KC. Diferenciais de mortalidade por causas nas faixas etárias limítrofes de idosos. Rev Bras Geriatr Geronto [Internet]. 2015 mar; [cited 2018 jul 18]; 18(1):85-94. Available from: http://www.scielo.br/pdf/rbgg/v18n1/1809-9823-rbgg-18-01-00085.pdf DOI: 10.1590/1809-9823.2015.14203

14. Bertoncello KCG, Cavalcanti CDK, Ilha P. Análise do perfil do paciente como vítima de múltiplos traumas. Cogitare Enferm [Internet]. 2012 out/ dez; [cited $2017 \mathrm{dec} 10$ ]; 17(4):717-23. Available from: https://revistas. ufpr.br/cogitare/article/viewFile/30380/19656

15. Feijó VBER, Junior LV, Souza RKT, Dias AO. Análise da demanda atendida em unidade de urgência com classificação de risco. Saúde debate [Internet]. 2015 sep; [cited 2018 jul 18]; 39(106):627-636 Available from: http://www.scielo.br/pdf/sdeb/v39n106/0103-1104sdeb-39-106-00627.pdf DOI: 10.1590/0103-110420151060003005

16. Silva MM, Esteves, LO, Moreira MC, Silva JA, Machado SC, Campos JF. Perfil de diagnósticos de enfermería en un hospital brasileño especializado en cuidados paliativos oncológicos. Ciencia Enferm [Internet]. 2013; [cited 2018 sep 05]; 19(1):49-59. Available from: https:// scielo.conicyt.cl/pdf/cienf/v19n1/art_05.pdf

17. Zilmer JGV, Lima LM, Feijó AM, Schwartz E, Hisse CN, Viegas AC, et al. Caracterização dos clientes em tratamento radioterápico em um serviço no Sul do Brasil. Rev Enferm UFSM [Internet]. 2013 mai/ago [cited 2018 jul 21]; 3(2):315-25. Available from: http://cascavel.ufsm.br/ revistas/ojs-2.2.2/index.php/reufsm/article/view/8595/pdf

18. Cunha BSS, Nascimento AS, Sá SPC. Perfil clinico e sociodemográfico de internação de idosos na unidade de emergência de um Hospital Geral. Estudos interdisciplinares sobre envelhecimento [Internet].2014 [cited 2018 aug 20]; 19(1):189-200. Available from: http://seer.ufrgs.br/ index.php/RevEnvelhecer/article/view/20963

19. Santos MT, Lima MADS, Zucatti PB. Serviços de emergência amigos do idoso no Brasil: condições necessárias para o cuidado. Rev Esc Enferm USP [Internet]. 2016; [cited $2018 \mathrm{sep} 05$ ]; 50(4):592-599. Available from: https://www.lume.ufrgs.br/bitstream/handle/10183/149447/001003791. pdf?...1 DOI: 10.1590/S0080-623420160000500008

20. Nascimento ERP, Silva SG, Souza BC, Souza DD, Netto AG. Ambiência de uma emergência hospitalar para o cuidado ao idoso: percepção dos profissionais de enfermagem. Esc Anna Nery [Internet]. 2015 abr/jun [cited 2018 aug 16]; 19(2):338-42. Available from: http://www.scielo.br/ pdf/ean/v19n2/1414-8145-ean-19-02-0338.pdf DOI: 10.5935/14148145.20150046

21. Ministério da Saúde (BR). Política Nacional de Atenção às Urgências. $3^{\mathrm{a}}$ ed. ampliada. Brasília (DF): Ministério da Saúde; 2006; [cited 2019 mar 26]. Available from: http://bvsms.saude.gov.br/bvs/publicacoes/ politica_nacional_atencao_urgencias_3ed.pdf 
22. Guedes HM, Martins JC, Chianca TC. Valor de predição do Sistema de Triagem de Manchester: avaliação dos desfechos clínicos de pacientes. Rev Bras Enferm [Internet]. 2015 jan/fev; [cited 2018 jul 18]; 68(1):45-51. Available from: http://www.scielo.br/scielo.php?script=sci_arttext\&pid $=$ S0034-71672015000100045DOI: $\mathrm{g} / 10.1590 / 0034-7167.2015680107 \mathrm{p}$

23. Oliveira, GN, Campanharo CRV, Lopes MCBT, Barbosa DA, Okuno MFP. Batista REA. Correlação das categorias de classificação de risco com aspectos clínicos e desfechos. Rev Latino-Am Enfermagem [Internet]. 2016; [cited 2018 aug 22]; 24: 01-09. Available from: http:// www.scielo.br/pdf/rlae/v24/pt_0104-1169-rlae-24-02842.pdf DOI: 10.1590/1518-8345.1284.2842

24. Caldas CP, Veras RP, Motta LB, Guerra ACLC, Carlos MJ, Trocado CVM. Atendimento de emergência e suas interfaces: o cuidado de curta duração a idosos. J Bras Econ Saúde [Internet]. 2015; [cited 2018 aug 20]; 1(7):62-69. Available from: http://files.bvs.br/ upload/S/2175-2095/2015/v7n1/a4757.pdf

25. Halfdanarson TR, Hogan WJ, Madsen BE. Emergencies in Hematology and Oncology. Mayo Clin Proc [Internet]. 2017 apr; [cited 2018 aug 30]; 92(4):609-41. Available from: https://www.mayoclinicproceedings.org/article/S0025-6196(17)30139-8/pdf DOI: 10.1016/j. mayocp.2017.02.008

26. Seow H, Brazil K, Sussman J, Pereira J, Marsahall D, Austin PC, et al. Impact of community based, specialist palliative care teams on hospitalisations and emergency department visits late in life and hospital deaths: a pooled analysis. BMJ [Internet]. 2014 jun; [cited 2018 sep 05]; 348:01-10. Available from: https://www.bmj.com/content/348/ bmj.g3496 DOI: 10.1136/bmj.g3496

27. Moura, ALC. A pessoa em fim de vida no serviço de urgência: abordagem terapêutica dos profissionais de saúde [dissertação]. Portugal: Escola Superior de Saúde, Instituto Politécnico de Viana do Castelo; 2017. Available from: http://repositorio.ipvc.pt/ bitstream/20.500.11960/1913/1/Andreia_Moura.pdf
28. Jensen ER, Potosky AL, Moinpour CM, Lobo T, Cella D, Hahn EA, et al. United States Population-Based Estimates of Patient Reported Outcomes Measurement Information System Symptom and Functional Status Reference Values for Individuals With Cancer. Journal of Clinical Oncology [Internet]. 2017 jun; [cited 2018 aug 30]; 35(17):1913-1920. Available from: https://www.ncbi.nlm.nih.gov/ pmc/articles/PMC5466008/pdf/JCO.2016.71.4410.pdf DOI: 10.1200/ JCO.2016.71.4410

29. Massa EB. Análise da Necessidade de Recurso Ao Serviço de Urgência de Doentes Oncológicos em Cuidados Paliativos [dissertação]. Portugal: Instituto de Ciências Biomédicas Abel Salazar, Universidade do Porto; 2009-2010. Available from: https://repositorio-aberto. up.pt/bitstream/10216/52776/2/Anlise $\% 20$ da $\% 20$ Necessidade $\% 20$ de\%20Recurso\%20Ao\%20Servio\%20de\%20Urgncia\%20de\%20 Doentes\%20Oncolgicos\%20em\%20Cuidados\%20Paliativos.pdf

30. Boaventura AP, Vedovato CA, Santos FF. Perfil dos pacientes oncológicos atendidos em uma unidade de emergência. Ciencia y Enfermeria [Internet]. 2015; [cited 2017 dec 10]; 21(2):51-62. Available from: https://scielo.conicyt.cl/pdf/cienf/v21n2/art_06.pdf

31. Yang Z, Yang R, Kwak MJ, Qdaisat A, Lin J, Begley CE, et al. Oncologic emergencies in a cancer center emergency department and in general emergency departments countywide and nationwide. Plos One [Internet]. 2018 feb; [cited $2018 \mathrm{sep} \mathrm{06];} \mathrm{13(2):e0191658.} \mathrm{Available}$ from: https://www.ncbi.nlm.nih.gov/pmc/articles/PMC5819770/pdf/ pone.0191658.pdf DOI: 10.1371/journal.pone.0191658 F

32. Delgado-Guay MO, Kim YJ, Shin SH, Chisholm G, Williams J, Bruera E. Avoidable and Unavoidable Visits to the Emergency Department Among Patients With Advanced Cancer Receiving Outpatient Palliative Care. Journal of Pain and Symptom Management [Internet]. 2015 mar; [cited 2018 aug 23]; 49(3):497-504. Available from: https://www. jpsmjournal.com/article/S0885-3924(14)00404-7/pdf DOI: 10.1016/j. jpainsymman.2014.07.007 